\author{
Дурбалова Н.І. \\ аспірант \\ кафедра менеджменту та логістики \\ Одеська національна академія харчових технологій \\ вул. Канатна, 112, м. Одеса, Україна, 65039 \\ E-mail: durbalova.nataly@ukr.net \\ ORCID: 0000-0002-0739-1265
}

\title{
ОСНОВНІ СКЛАДОВІ ІННОВАЦІЙНОЇ СТРАТЕГІЇ РОЗВИТКУ ХЛІБОПЕКАРСЬКИХ ПІДПРИЄМСТВ
}

У статті показано стан хлібопекарської промисловості і тенденції її розвитку в Україні. Доведено необхідність впровадження стратегій саме інноваційного розвитку як єдино можливого напряму розвитку підприємств промисловості. Розглянуто типи інноваційних стратегій і виявлено, які саме необхідно застосовувати для ефективного розвитку підприємств. Відзначено, що робота в статті було проведена з метою всебічного і ґрунтовного дослідження основних інноваційних стратегій розвитку щодо хлібопекарських підприємств. Показані результати проведеного аналізу типів інноваційних стратегій розвитку та обґрунтовано виділення синергетичної стратегії як певного типу. Підкреслено, що синергетична стратегія об'єднує підприємства на основі їхніх наукових потенціалів, наслідком чого є прискорення генерації і практичного впровадження інновацій. Було виявлено, що реалізація зазначеної синергетичної інноваційної стратегії за допомогою підсумовування потенціалів вітчизняних інноваційно орієнтованих хлібопекарських підприємств призведе до довготривалої конкурентоспроможності $\mathrm{i}$, як результат, прибутковості.

Ключові слова: хлібопекарські підприємства, інновація, інноваційна стратегія, інноваційна стратегія розвитку, синергетична стратегія.

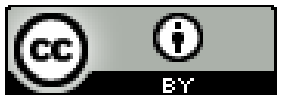

This work is licensed under a Creative Commons Attribution 4.0 International License http://creativecommons.org/licenses/by/4.0/
Постановка проблеми та їі зв'язок з важливими науковими та практичними завданнями. Сьогодні необхідною умовою виживання хлібопекарських підприємств в зовнішніх мінливих умовах виступає впровадження інновацій. Значення інноваційної стратегії розвитку для сектору хлібопекарських підприємств важко переоцінити, оскільки саме він дозволяє забезпечити досягнення постійних конкурентних переваг і конкурентоспроможність стратегічно значущої продукції. Саме тому зазначене обумовлює необхідність дослідження, аналізу та генерування інноваційної стратегії розвитку для хлібопекарських підприємств.

Аналіз останніх публікацій по проблемі. Дослідженню питань інноваційного розвитку в роботі підприємства присвячені роботи економістів: В. Амітана, В. Гамана, В. Геєця, С. Ілляшенко, В. Македона [1], О. Поповича, Н. Тарнавської, В. Федотової, 3 . Шершневої, Л. Шульгиной [2] та ін. Проблематикою формування стратегій підприємств цікавилися численні закордонні вчені: Д. Аакер, І. Ансофф, Л. Кларк, В. Міллер, М. Портер, Р. Фатхутдінов та ін., які провели важливі дослідження в цій сфері. Однак, незважаючи на значні напрацювання вчених, проблематика інноваційних стратегій розвитку підприємств, в тому числі, хлібопекарських, досі залишається актуальною і потребує продовження досліджень. Так, умови постійного розвитку ринкового середовища хлібопекарських підприємств визначають потребу вдосконалення підходів до формування механізмів інноваційного розвитку, що вимагає розробки нових стратегій інноваційного розвитку.

Формулювання цілей дослідження. Метою статті $є$ всебічне і грунтовне дослідження основних типів існуючих інноваційних стратегій розвитку для хлібопекарських підприємств та обгрунтувати доцільність виділення в окремий тип стратегій інноваційного розвитку синергетичної стратегії.

Виклад основних результатів та їх обгрунтування. Значимість хлібопекарської промисловості для стратегічного успішного розвитку економіки України важко переоцінити. Діяльність підприємств базується на розумінні потреб споживачів із зростаючими вимогами до якості продукції на тлі скорочення середньодушового споживання, динамічних змін кон'юнктури ринку і високого рівня конкуренції 3 проявами експансії. Український хлібний ринок сформувався під впливом радянської системи 3 метою нагодувати населення хлібом. Тоді замість пекарень будувалися хлібозаводи, а великотоварне виробництво було зорієнтовано на великі обсяги продукції. Сучасні тенденції розвитку хлібопекарських підприємств ознаменувалися появою приватних підприємств (зросла кількість міні-пекарень) з малим асор - 
тиментом і скороченням обсягів споживання хліба. Зниження споживання хліба з 6,7 млн. тон у 1990 p. до майже 1 млн. тон у 2018 р. обумовлено як скороченням обсягів виробництва, так і потребами внутрішнього ринку. Цікаво, що виробництво в Україні виробів нетривалого зберігання зменшилось на $10,7 \%$ у 2019 році [3].

Важливо зазначити, що в країні відбувається постійне зниження виробництва стратегічного продукту для життєдіяльності населення в середньому на $10 \%$. Особливо згубним є трикратне зменшення 3 2000 по 2019 роки (з 2,5 млн. т до майже 850-860 тис. т) [4]. Причиною таких зрушень може бути те, що структура харчування різко змінилась від відносно недорогих продуктів хлібобулочної промисловості до корисніших та дорожчих. Вважаємо за доцільне провести дослідження основних типів існуючих стратегій інноваційного розвитку хлібопекарських підприємств та обгрунтувати виділення в окремий тип стратегій інноваційного розвитку синергетичну стратегію.

При цьому на сьогодні в Україні слід констатувати наявність у хлібопекарських підприємств значних проблем, до основних з яких слід віднести низьку інноваційну активність, застарілі основні виробничі фонди, низький рівень завантаження виробничих потужностей, низький рівень конкурентоспроможності багатьох видів продукції, відсутність реальних джерел фінансування, брак оборотних коштів i iн. Зазначене обумовлює необхідність активізації розвитку підприємств, враховуючи конкурентні переваги і забезпечуючи випуск конкурентоспроможної продукції, що можливо тільки на основі створення і застосування інновацій. Таким чином, можна підсумувати, що адаптація національних хлібопекарських підприємств до умов ринкової сучасної економіки, що характеризується жорсткістю і мінливістю ринкового середовища при одночасному загостренні конкурентної боротьби на світовому і національному ринках, пов'язана із інноваціями і інноваційним розвитком, як рушійними силами економічного зростання. Саме перехід на шлях інноваційного розвитку дозволить забезпечити підприємствам стійке функціонування за рахунок успішного конкурування на основі впровадження інновацій, випуску конкурентного продукту 3 високими споживацькими та естетичними характеристиками, ефективного використання власного виробничого потенціалу. У свою чергу це зумовлює гостру потребу формувати стратегії розвитку, орієнтованих на активізацію інноваційної активності на хлібопекарських підприємствах. Під інноваційною стратегією розуміють сукупність дій і методів ведення інноваційної діяльності, яка забезпечує досягнення конкурентних переваг розробкою та впровадженням інновацій [5].

Відзначимо, що існує значна кількість класифікацій, кожна 3 яких виділяє різні типи інноваційних стратегій. Розглянемо основні типи стратегій інноваційного розвитку, які можуть застосовуватися вітчизняними хлібопекарськими підприємствами, більш детально. Так, наступальна (агресивна) застосовується в діяльності підприємств, що виносять на ринок товари з однозначно іншими якостями для споживача. В рамках зазначеної інноваційної стратегії виділяють наступні різновиди [6]:

- стратегія досягнення переваг по витратах, що реалізується за рахунок здешевлення виробничої діяльності внаслідок впровадження нових технологічних методів;

- стратегія створення нових ринків, яка впроваджується шляхом розробки і випуску абсолютно нових видів продукції;

- стратегія орієнтації на певний сегмент покупців з метою максимального задоволення потреб певної групи споживачів.

Захисні інноваційні стратегії включають такі різновиди $[6$, с. 18$]$ :

- оборонна стратегія сконцентрована у напрямі підтримки існуючих позицій підприємствконкурентів на певних ринках. Головним їі компонентом $\epsilon$ оптимізація співвідношення «витрати - результати» щодо інноваційних процесів. Вона є характерною для підприємств, які повністю задоволені своїми ринковими позиціями, і спрямована на їхнє утримання. Важливим є те, що параметри певної продукції системно покращуються, але не суттєво. Такі підприємства зазвичай не зацікавлені в подальшому інноваційному розвитку, тому що мають намір і в подальшому використовувати вигоду від свого лідерства, зокрема і шляхом створення обмежувальних вхідних бар'єрів;

- імітаційна стратегія застосовується майже всіма фірмами в певній мірі, та тими компаніями, які не встигли стати піонерами щодо просування нововведень на ринок. В першу чергу вона є прийнятною для підприємств, що не являються лідерами щодо інновацій, проте мають достатній потенціал для оперативного і результативного дублювання споживчих властивостей запропонованих нововведень провідних конкурентів. Передбачає виділення таких підтипів [7]:
а) наслідування лідеру;
б) диференціація;
в) копіювання;
г) удосконалення.

Також важливо, що, з урахуванням важливості хлібопекарської промисловості для економіки країни в цілому, а також $з$ огляду на те, що хлібопекарська промисловість є стратегічною для економічної безпеки країни, доцільним є виділення стратегій інноваційного розвитку хлібопекарських підприємств на основі активної державної підтримки або ж при відсутності такої. Так, з урахуванням зазначеного параметра Шульгіна Л.М. і Юхименко В.В виділяють наступні види стратегій інноваційного розвитку [2, с. 133]:

- регульована стратегія - передбачає цільове виділення бюджетних коштів на реалізацію проектів 3 розвитку інфраструктури і обов'язкове обгрунтування бюджетної ефективності реалізації цих проектів (тобто розрахунок умов повернення коштів до бюджету у вигляді додаткових надходжень, які виникають в результаті реалізації проектів). Наслідки: можливість 
управлінських, організаційних, технологічних і ін.

- інерційна стратегія - передбачає відсутність цільових заходів підтримки державою і збереження негативних тенденцій розвитку хлібопекарської промисловості, таких як відставання бізнес-процесів від світових, знос обладнання тощо. Фінансування інфраструктури хлібопекарської промисловості зберігається на поточному рівні. Відсутність державного фінансування призводять до неможливості реалізації проектів, спрямованих на розвиток інфраструктури. Наслідки: недофінансування і подальша деградація інфраструктури хлібопекарської промисловості.

Крім того, вважаємо за доцільне звернути увагу на те, що в жорстких конкурентних умовах відокремлені, самостійно функціонуючі хлібопекарські підприємства не мають гарантій стабільного функціонування на основі ефективного досягнення поставлених цілей. Такий стан справ обумовлений тим, що останнім часом значного поширення набули різні форми кооперації, які є складовими елементами стратегій розвитку підприємств, в тому числі, інноваційних. Таким чином, на сьогодні для підприємств хлібопекарської промисловості можна наголошувати про доцільність виділення в окремий вид інноваційних стратегій синергетичної стратегії інноваційного розвитку, яка має в своїй основі об'єднання підприємств, в першу чергу, їх наукових потенціалів, що призводить до прискорення генерації і практичного застосування інновацій. Така необхідність, в першу чергу, обумовлюється тим, що в ринковій економіці успішна конкуренція стає функцією командної боротьби, а не суперництва певних економічних суб'єктів. Одним 3 найважливіших конкурентних переваг підприємств сьогодні стають процеси інтеграції, кооперації, об'єднання і взаємодії - прикладної науки і реального виробництва, інновацій та інвестицій, підприємств між собою - замість ізольованого функціонування поодинці.

Кооперація, інтеграція і співробітництво на основі принципу конкуренції як способи організації суб'єктів господарювання в економіці призводять до з'єднання в рамках об'єднання підприємств конкурентних і кооперативних відносин, які виступають джерелом колективних конкурентних переваг для всіх учасників об'єднання, що сприяє створенню і розширенню інновацій і створює значні конкурентні бар'єри для інших учасників ринку. Саме це на сьогодні стає фундаментальним джерелом прибутку підприємств i економічного розвитку суспільства в цілому.

Таким чином, доцільно підсумувати, що в сучасних умовах процеси кооперації та інтеграції тісно поєднані з інноваційною складовою діяльності підприємств. Це знаходить відображення в процесах організації підприємств в різноманітні інтегровані структури, що забезпечує ефективні економічні, науково-технічні і організаційні зміни для всіх учасників. Глобальною тенденцією сучасного етапу вважають утворення різних добровільних об'єднань - 3 метою проведень спільних наукових досліджень, впровадження більш ризикованих наукових проектів тощо, що формує мережеву економіку.
Як зазначає С. Соколенко [8, с. 17], сьогодні не компанії конкурують між собою, а найефективніші ланцюги доданої вартості захоплюють глобальний ринок. Значна кількість провідних країн активно залучають стратегічні альянси, а також «кластерний підхід» для генерування стратегії власного інноваційного розвитку. Відзначимо, що реалізовувати синергетичну інноваційну стратегію підприємства можуть як в межах використання наступальних стратегій, так i стратегій захисних. При цьому стверджують, що об'єднання зусиль дозволяє підприємствам активізувати інноваційну діяльність і набагато легше здійснювати інноваційні прориви, що доводить необхідність використання зазначеної стратегії хлібопекарських підприємств в Україні. Наприклад, досить часто підприємство не здатне застосовувати успішну інноваційну діяльність, так як реалізація інноваційних процесів обумовлює необхідність значних витрат. Зовсім інакше складаються умови, коли інноваційного розвитку дотримуються одночасно кілька підприємств, об'єднаних в мережеву структуру. Так вони скорочують свої витрати завдяки спільній прогресивній технологічній кооперації, що компенсує витрати на інноваційну діяльність і дозволяє стабільно здійснювати іiі протягом тривалого періоду. До того ж, в такому об'єднанні інновації - продукт діяльності декількох підприємств або дослідних інститутів - поширюється по мережі взаємозв'язків в загальному економічному просторі об'єднання. На сьогодні об'єднання підприємств $є$ однією 3 найефективніших форм організації інноваційних процесів, при якій на ринку конкурують вже не окремі підприємства, а цілі комплекси, які скорочують свої трансакційні витрати завдяки спільній технологічній кооперації компаній [9].

Реалізація синергетичної інноваційної стратегії забезпечує підприємствам безсумнівні переваги, особливо, що стосується формування нових знань, НДДКР і ноу-хау. Об'єднання ресурсів та інноваційних потенціалів, довгострокова взаємодія і співпраця фірм, розвиток їхньої взаємної довіри набагато швидше приводять до загальної генерації нововведень, причому вартість останніх $є$ меншою, а швидкість їхньої генерації підвищується [10].

Відзначимо, що об'єднання підприємств може бути інноваційним не тільки через безпосередню спрямованість на нововведення. Інновації можуть безпосередньо виникати завдяки більш досконалій організації діяльності підприємств і процесу виробництва, формування стійкої взаємодії з усіма учасниками, отриманню та поширенню необхідних знань i технологій, тісної взаємодії та кооперації при одночасному збереженні конкуренції, яка $є$ двигуном інновацій в межах створеного об'єднання. Різноманітні джерела інформації, що розширюють коло наявних знань, і численні постійні зв'язки учасників об'єднання полегшують комбінування наявних факторів конкурентних переваг, що стає важливою передумовою для виникнення інновацій - продуктових, управлінських, організаційних, технологічних і ін. Відмінною особливістю об'єднання підприємств можна вважати 
виникнення в його межах ефекту масштабу виробництва та ефекту охоплення $[11,12]$.

Варто відзначити, що особливістю інноваційної стратегії розвитку для хлібопекарських підприємств України є узгодження економічних запитів виробників та соціальних інтересів споживачів і суспільства. Основою ефекту масштабу виробництва $\epsilon$ наявність у вигляді однісї з фірм ядра інноваційного об'єднання для певного виробництва. Ефект охоплення в загальному вигляді виникає при реалізації фактору технології, що можливо використати одночасно у виробництві кількох видів продукції. При групуванні фірм цей ефект суттєво посилюється, через виникнення можливості використати багатофункціональний фактор на різноманітних підприємствах із мінімізацією витрат щодо його передачі. Стає можливою також економія внаслідок скорочення витрат на розробку різних технологій для різноманітних областей застосування завдяки розвитку в об'єднанні однієї технології, яка $є$ базовою. При дії всіх зазначених ефектів навіть неприбуткові підприємства - учасники об'єднання - мають змогу подолати негативне значення рентабельності завдяки спеціалізації, що гарантує зменшення собівартості та збільшення продуктивності праці. Отже, за рахунок об'єднання підприємства отримують додаткові конкурентні переваги [11, $12]$.

Крім того, об'єднання підприємств зазвичай призводить до появи критичного ефекту, який виникає, коли для здійснення первинної інновації необхідно провести значну кількість вторинних змін, внаслідок чого прибуток може бути менше витрат від реорганізації. В межах об'єднання фірми можуть мінімізувати витрати на вторинні зміни, що дає їм можливість впроваджувати різноманітні інновації [12, с. 101]. Однією з першочергових причин низького рівня інноваційної активності національних хлібопекарсь- ких підприємств, що здійснює негативний вплив на процес переходу економіки на інноваційний тип розвитку, є відсутність у вітчизняних хлібопекарських підприємств чітко сформульованих стратегій інноваційного розвитку. При цьому, реалізація синергетичної інноваційної стратегій шляхом об'єднання зусиль вітчизняних хлібопекарських підприємств, що створить можливості для впровадження інновацій, як в окремих видах продукції, так і в сукупному бізнесі, дозволить їм досягти найвищих результатів від раціонального поєднання зусиль і буде сприяти досягненню довгострокової конкурентоспроможності та прибутковості в мінливому ринковому середовищі.

Висновки та перспективи подальших досліджень. Таким чином, в проведеному дослідженні обгрунтовано необхідність впровадження стратегій інноваційного розвитку як єдино можливого напряму розвитку підприємств досліджуваної промисловості. Також важливо підсумувати, що на сьогоднішній день існує значна кількість класифікацій, кожна 3 яких виділяє різні типи інноваційних стратегій. Розглянуті типи інноваційних стратегій дають можливість визначити, які з них слід використовувати для розвитку хлібопекарських підприємств. Метою статті було дослідити основні типи стратегій інноваційного розвитку хлібопекарських підприємств. Результати дослідження полягають у тому, що на основі аналізу типів стратегій інноваційного розвитку в окремий тип виділяється синергетична стратегія, в основі якої лежить об'єднання підприємств, в першу чергу їхнього наукового потенціалу, що прискорює формування i практичне застосування інновацій. Дослідження показало, що реалізація синергетичних інноваційних стратегій шляхом об'єднання зусиль вітчизняних пекарень допоможе їм досягти довгострокової конкурентоспроможності та прибутковості.

\section{Література}

1. Македон В. В., Рубець Д. С. Стратегічний інноваційний розвиток підприємств: теорія та методологія // Вісник НТУ «Харківський політехнічний інститут». 2013. № 45 (1018). С. 75-86.

2. Шульгіна Л. М., Юхименко В. В. Інноваційний розвиток підприємств: формування стратегій: монографія. К. Univest PrePress, 2015. 212 с.

3. Офіційний сайт Державної служби статистики України: веб-сайт. URL: http://www.ukrstat.gov.ua/. (дата звернення: 20.07.2020).

4. Украинцы едят все меньше хлеба // Укрінформ: [Веб-сайт]. URL: https://www.ukrinform.ru/rubriceconomy/2852514-ukraincy-edat-vse-mense-hleba-berezem-koselki-zdorove-figuru.html (дата звернення: 20.07.2020).

5. Підвищення конкурентоздатності економіки областей Заходу та Півдня України на основі формування нових виробничих систем (кластерів): монографія / заг. ред. С.І. Соколенка. К., 2005. 238 с.

6. Письмак В. Нові форми організації інноваційного процесу // Економіст. 2003. № 9. С. 53-65.

7. Ганущак Л. М. Шляхи використання зарубіжного досвіду управління інноваційнім потенціалом підприємств в Україні // Актуальні проблеми економіки. 2006. № 4 (58). С. 135-142.

8. Марченко В. Н. Перспективи експортно-орієнтованого розвитку виробництва вибухозахищеного електрообладнання в Україні шляхом створення кластера // Економічний вісник Донбасу. 2004. № 1. С. 51-56.

9. Мінгальова Ж., Ткачова Ж. Кластери та формування структури регіону // Світова економіка і міжнародні відносини. 2000. № 5. С. 97-102.

10. Kalaman O., Savenko I., Dolynska O. Conceptual positions of enterprise strategy functioning // Food Industry Economics. 2019. Vol.11, Issue 3. P. 50-58. doi: 10.15673/fie.v11i3.1461

11. Bondarenko S., Lagodienko V., Sedikova I. \& Kalaman O. Application of Project Analysis Software in Project Management in the PreInvestment Phase. // Journal of Mechanical Engineering and Technology. 2018. Vol. 9 (13), P. 676-684. 
12. Durbalova, N. Sedikova, I. (2019). Strategic management competitive potential of the enterprise // Food Industry Economics. 2019. Vol.11, Issue 4. P. 58-64. doi: 10.15673/fie.v11i4.1547

13. Седікова I. О. Управління інноваційною діяльністю підприємств кондитерської галузі // Науковий вісник УНУ: серія: Міжнародні економічні відносини та світове господарство. 2018. Вип.18(3).С.55-59.

Стаття надійшла 1.08.2020

Стаття прийнята до друку 15.08.2020

Дурбалова Н.И.

Доступно в мережі Internet 15.10.2020

аспирант

кафредра менеджмента и логистики

Одесская национальная академия пищевых технологий

ул. Канатная, 112, г. Одесса, Украина, 65039

E-mail: durbalova.nataly@ukr.net

ORCID: 0000-0002-0739-1265

\section{ОСНОВНЫЕ СОСТАВЛЯЮЩИЕ ИННОВАЦИОННОЙ СТРАТЕГИИ РАЗВИТИЯ ХЛЕБОПЕКАРСКИХ ПРЕДПРИЯТИЙ}

В статье показано текущее состояние хлебопекарной промышленности Украины и тенденции ее развития. Доказано, что современная адаптация отечественных хлебопекарских предприятий к рыночным условиям, характеризующимся жесткостью и изменчивостью среды при усилении конкуренции на рынках, напрямую зависит от инноваций и инновационного развития как драйвера экономического роста. Показано, что инновационный путь развития гарантирует стабильную и успешную работу предприятий хлебопекарской промышленности за счет успешной конкуренции, основанной на инновациях, производстве конкурентоспособной продукции с высокими потребительскими и эстетическими характеристиками, интенсивном использовании их собственного производственного потенциала. Подчеркивается, что это требует формирования инновационной стратегии хлебопекарных предприятий, которая будет направленна на активизацию инновационной активности. Отражено, что инновационная стратегия представляется совокупностью инновационных действий и методов, обеспечивающей конкурентное преимущество путем разработки и внедрения инноваций.

Обоснована необходимость внедрения стратегий инновационного развития как единственно возможного направления развития отрасли. Отмечается, что на сегодняшний день существует значительное количество классификаций, в каждой из которых выделены разные типы инновационных стратегий. Рассмотрены типы инновационных стратегий и определены, какие из них следует использовать для развития хлебопекарных предприятий. Цель статьи заключалась в исследовании типов инновационных стратегий развития хлебопекарных предприятий. Результаты исследования заключаются в том, что на основе их анализа в отдельный тип выделяется синергетическая стратегия. Такой тип основан на объединении предприятий, базирующемся на их научном потенциале, что ускоряет формирование и практическое использование инноваций. Проведенное исследование показало, что практика применения в сегодняшних реалиях синергетической инновационной стратегии через объединение усилий отечественных пекарен поможет им достичь прибыльности.

Ключевые слова: хлебопекарские предприятия, инновация, инновационная стратегия, инновационная стратегия развития, синергетическая стратегия.

\section{Durbalova N.}

Postgraduate student

Department of Management and Logistics

Odessa National Academy of Food Technologies

Kanatna str., 112 Odesa, Ukraine, 65039

E-mail: durbalova.nataly@ukr.net

ORCID: 0000-0002-0739-1265

\section{MAIN COMPONENTS OF INNOVATIVE STRATEGY OF BAKERY ENTERPRISES DEVELOPMENT}

The article shows the current state of the bakery industry in Ukraine and trends in its development. It has been proved that today the adaptation of national bakeries to market economy, which is characterized by rigidity and variability of the market environment while intensifying competition in global and national markets, is directly related to innovations and innovative development as a driver of economic growth. It has been shown that the transition to the path of innovative development will ensure stable functioning to the en- 
terprises of the industry due to successful competition based on innovation (production, technological, managerial, etc.), production of a competitive product with high consumer and aesthetic characteristics, efficient use of own production potential. It has been emphasized that this necessitates the formation of innovational strategies aimed at intensifying of innovation activity in bakery enterprises. It has been reflected that the innovation strategy is understood as a set of actions and methods of innovation, which provides a competitive advantage through the development and implementation of innovations.

The necessity of innovative development strategies introduction as the only possible direction of branch development has been proved. It has been noted that today there are a significant number of classifications, each of which identifies innovation strategies of different types. The innovation strategies types have been considered and it has been identified which ones should be used for the development of bakery enterprises. The purpose of the article is to study the main strategies types for bakery enterprises innovative development. The results of the research are to distinguish synergetic strategy is a separate type on the basis on their analysis. Such type is based on integration of the enterprises according to their scientific potential, which accelerates formation and practical applications of innovations. The study found that the implementation of synergetic innovation strategies by combining the efforts of domestic bakeries will help them achieve long-term competitiveness and profitability.

Key words: innovation, innovation strategy, innovative development strategy, synergetic strategy, bakery enterprises.

\section{References}

1. Makedon, V. V., \& Rubets, D. S. (2013). Stratehichnyi innovatsiinyi rozvytok pidpryiemstv: teoriia ta metodolohiia. Visnyk NTU «Kharkivskyi politekhnichnyi instytut», (45 (1018)), 75-86.

2. Shulhina, L. M., \& Yukhymenko, V. V. (2015). Innovatsiinyi rozvytok pidpryiemstv: formuvannia stratehii. Kyiv: Univest PrePress.

3. Ofitsiinyi sait Derzhavnoi sluzhby statystyky Ukrainy. Retrieved July 20, 2020, from http://www.ukrstat.gov.ua/

4. Ukraintsyi edyat vse menshe hleba (2020). Retrieved July 20, 2020, from https://www.ukrinform.ru/rubriceconomy/2852514-ukraincy-edat-vse-mense-hleba-berezem-koselki-zdorove-figuru.html

5. Sokolenko, S. I. (2005). Pidvyshchennia konkurentozdatnosti ekonomiky oblastei Zakhodu ta Pivdnia Ukrainy na osnovi formuvannia novykh vyrobnychykh system (klasteriv). Kyiv.

6. Pysmak, V. (2003). Novi formy orhanizatsii innovatsiinoho protsesu. Ekonomist, (9), 53-65.

7. Hanushchak, L. M. (2006). Shliakhy vykorystannia zarubizhnoho dosvidu upravlinnia innovatsiinim potentsialom pidpryiemstv v Ukraini. Aktualni problemy ekonomiky, (4 (58)), 135-142.

8. Marchenko, V. N. (2004). Perspektyvy eksportno-oriientovanoho rozvytku vyrobnytstva vybukhozakhyshchenoho elektroobladnannia v Ukraini shliakhom stvorennia klastera. Ekonomichnyi visnyk Donbasu, (1), 51-56.

9. Minhalova, Zh., \& Tkachova, Zh. (2000). Klastery ta formuvannia struktury rehionu. Svitova ekonomika $i$ mizhnarodni vidnosyny, (5), 97-102.

10. Kalaman, O., Savenko, I., \& Dolynska, O. (2019). Conceptual positions of enterprise strategy functioning. Food Industry Economics, 11(3), 50-58. doi: 10.15673/fie.v11i3.1461

11. Bondarenko, S., Lagodienko, V., Sedikova, I., \& Kalaman, O. (2018). Application of Project Analysis Software in Project Management in the PreInvestment Phase. Journal of Mechanical Engineering and Technology, 9(13), 676-684.

12. Durbalova, N., \& Sedikova, I. (2019). Strategic management competitive potential of the enterprise. Food Industry Economics, 11(4), 58-64. doi: 10.15673/fie.v11i4.1547

13. Sedikova, I. O. (2018). Upravlinnia innovatsiinoiu diialnistiu pidpryiemstv kondyterskoi haluzi. Naukovyi visnyk UNU, (18 (3)), 55-59.

Received 1 August 2020

Approved 15 August 2020

Цитування згідно ДСТУ 8302:2015

Available in Internet 15.10.2020

Дурбалова Н.І. Основні складові інноваційної стратегії розвитку хлібопекарських підприємств // Економіка харчової промисловості. 2020. Т.12, вип. 3. С. 60-65. doi: 10.15673/fie.v12i3.1817

Cite as APA style citation

Durbalova, N. (2020). Main components of innovative strategy of bakery enterprises development. Food Industry Economics, 12(3), 60-65. doi: 10.15673/fie.v12i3.1817 